\title{
One-Pot Synthesis of 1-Octyl $\beta$-D-Glucoside from Cellulose and 1-Octanol in Combination of Cellulase and $\beta$-Glucosidase
}

\author{
Shuichi Matsumura, Hiroshi Tsuruta, and Kazunobu Toshima \\ Department of Applied Chemistry, Faculty of Science and Technology, Keio University \\ (3-14-1, Hiyoshi, Kohoku-ku, Yokohama-shi 223-8522)
}

\begin{abstract}
Octyl $\beta$-D-glucoside was prepared by one-pot reaction of cellulose and 1-octanol using the combination of cellulase and $\beta$-glucosidase. In combination with $0.1 \%$ cellulase from Aspergillus niger and $0.5 \% \beta$-glucosidase from Almonds, 1-octyl $\beta$-D-glucoside was produced by as much as $245 \mathrm{mg} / \mathrm{g}$ cellulose during the incubation of 1-octanol saturated with $100 \mathrm{mM}$ acetate buffer (pH 5.0) and $\alpha$-cellulose at $37^{\circ} \mathrm{C}$ for $5 \mathrm{~d}$.

Key words : octyl glucoside, nonionic surfactant, cellulase and $\beta$-glucosidase, cellulose, one-pot enzymatic synthesis
\end{abstract}

\section{Introduction}

Carbohydrate is one of the alternative feedstocks for the preparation of surfactants because it is an inexpensive, renewable and biodegradable raw material. Among the carbohydrates, cellulose is the most abundant, renewable natural polymer on the earth.

Alkyl glycosides, such as octyl glucoside, are of particular interest because, in addition to their potential biological and pharmaceutical applications ${ }^{1 \sim 12)}$, they are made from naturally occurring renewable resources of fatty alcohols and sugars. Furthermore, from an ecological point of view as well as an energy consideration, alkyl glycosides will be some of the most promising candidates of new surfactants in the next generation. Recently, alkyl polyglycosides have been commercially produced from monomeric D-glucose and a fatty alcohol in the presence of a catalyst, and they have been proven to show excellent properties of both surfactants and biodegradability. However, they are a mixture of several homologous and isomeric compounds, which are not suited for biological and pharmaceutical applications. Furthermore, the conventional preparation of alkyl glycosides was carried out using monomeric sugar units which are obtained from polysaccharides, such as starch, by hydrolysis. The direct reaction of polysaccharides

Corresponding author: Shuichi MATSUMURA and a fatty alcohol may be advantageous for industrial production because the hydrolysis of polysaccharides and the purification process for monomeric sugar will be omitted. Under these circumstances, the enzymatic synthesis of alkyl glycosides will be the more attractive method.

The enzymatic synthesis of alkyl glycosides, such as alkyl glucoside ${ }^{13) \sim 18)}$, alkyl galactoside ${ }^{19)-21)}$ and alkyl xyloside ${ }^{22}$ have been reported. Recently, an alkyl oligoxyloside could be prepared by the onepot reaction of xylan and a fatty alcohol using microbes. We previously reported the one-pot enzymatic synthesis of alkyl xylobioside and xyloside using a xylan-assimilating strain, $A u$ reobasidium pullulans KK415 (ATCC 201145), as the enzyme source ${ }^{23), 24}$. Also, heptyl xyloside was prepared by the one-pot reaction of xylan and heptanol using the culture broth of Penicillium sp. by Shinoyama et al. ${ }^{25}$. However, the one-pot synthesis of alkyl glycosides using cellulose has not been reported.

This paper describes the one-pot synthesis 1octyl $\beta$-D-glucoside from $\alpha$-cellulose and 1-octanol using cellulase and $\beta$-glucosidase.

\section{Experimental}

\subsection{Materials and measurements}

$\alpha$-Cellulose was purchased from the Sigma Chemical Co. (St. Louis, MO, USA). 1-Octyl $\beta$-Dglucoside as the authentic sample was prepared according to a previous paper ${ }^{8)}$. Cellobiose was purchased from Tokyo Kasei Kogyou Co., 
Ltd.(Tokyo, Japan). The other materials were of the highest available purity and used as purchased unless stated otherwise. Cellulase (EC 3.2.1.4) from Aspergillus niger ( $0.45 \mathrm{unit} / \mathrm{mg}$ solid, according to the supplier) and $\beta$-glucosidase (EC 3.2.1.21) from Almonds (5.5 unit/mg solid, according to the supplier) were purchased from the Sigma Chemical Co. (St. Louis, MO, USA). The enzymes were used without further purification. The 1-octyl $\beta$-D-glucosides were analyzed using high-performance liquid chromatography (HPLC) with a refractive index detector (RI) and a commercial HPLC column (Inertosil ODS-2, GL Sciences Inc., Tokyo, Japan, acetonitrile/water $=$ $3 / 2(\mathrm{v} / \mathrm{v})$ as the eluent) calibrated with the chemically synthesized authentic standard. The ${ }^{1} \mathrm{H}$ and ${ }^{13} \mathrm{C}$ NMR spectra were recorded using a JEOL model GSX-270 Fourier Transform Spectrometer (Tokyo, Japan) operating at 270 and $67.5 \mathrm{MHz}$, respectively, with complete proton decoupling in $\mathrm{CD}_{3} \mathrm{OD}$ at $25{ }^{\circ} \mathrm{C}$.

\section{$2 \cdot 2$ Preparation of 1-octanol saturated with acetate buffer ${ }^{14)}$}

A mixture of $100 \mathrm{mM}$ acetate buffer (pH 5.0) and 1-octanol was preequilibrated with stirring overnight at $25^{\circ} \mathrm{C}$. The heterogeneous mixture was then centrifuged at $3000 \mathrm{rpm}$ for $5 \mathrm{~min}$ to obtain a transparent supernatant as the buffer saturated 1octanol for the enzymatic reaction.

\section{$2 \cdot 3$ Preparation of 1-octyl $\beta$-D-glucoside}

1-Octyl $\beta$-D-glucoside was prepared by the incubation of cellulose and 1-octanol in the presence of cellulase and $\beta$-glucosidse as shown in Scheme 1. A typical preparation procedure is as follows. A mixture of $\alpha$-cellulose, 1-octanol saturated with $100 \mathrm{mM}$ acetate buffer (pH 5.0) and the enzymes was incubated in a glass tube with stirring using a magnetic stirring bar at $37^{\circ} \mathrm{C}$. The yield of the 1-octyl $\beta$-D-glucoside was periodically measured as follows. An aliquot $(1.0 \mathrm{~mL})$ of the reaction mixture was filtered through a celite pad to remove the enzyme and unreacted $\alpha$-cellulose. The celite pad was then washed with ethanol. A small amount of water was added to the combined filtrate and repeatedly azeotropically evaporated in a vacuum to give the crude product. The crude product was directly analyzed by HPLC using the authentic standard. For the structure analysis, the crude product was purified by silica gel column chromatography $\left[\left(\mathrm{SiO}_{2}, \mathrm{CHCl}_{3} / \mathrm{CH}_{3} \mathrm{OH}=3 / 1\right.\right.$ $(\mathrm{v} / \mathrm{v})]$ to give 1-octyl $\beta$-D-glucoside $\left[R_{f}=0.6\right.$, $\left.\mathrm{CHCl}_{3} / \mathrm{CH}_{3} \mathrm{OH}=3 / 1(\mathrm{v} / \mathrm{v})\right]$. The structures of these compounds were confirmed by HPLC, elemental analysis, and ${ }^{1} \mathrm{H}$ NMR and ${ }^{13} \mathrm{C}$ NMR spectroscopies. 1-Octyl $\beta$-D-glucoside: Elemental analysis, Found : $\mathrm{C}, 57.65 ; \mathrm{H}, 9.78 \%$. Calculated for $\mathrm{C}_{14} \mathrm{H}_{28} \mathrm{O}_{6}$ : C, $57.51 ; \mathrm{H}, 9.65 \%$. ' $\mathrm{H}$ NMR (270 $\left.\mathrm{MHz}: \mathrm{CD}_{3} \mathrm{OD}\right): \delta 0.88(3 \mathrm{H}, \mathrm{t}, J=4.0 \mathrm{~Hz}), 1.25$ $(10 \mathrm{H}, \mathrm{m}), 1.52(2 \mathrm{H}, \mathrm{m}), 3.00-3.87(8 \mathrm{H}, \mathrm{m}), 4.16$ $(1 \mathrm{H}, \mathrm{m}) .{ }^{13} \mathrm{C}$ NMR $\left(67.5 \mathrm{MHz}: \mathrm{CD}_{3} \mathrm{OD}\right): \delta 14.4$, 23.7, 27.1, 30.4, 30.6, 30.8, 33.0, 62.7, 70.9, 71.6, $75.1,77.8,78.1,104.3$.

\section{Results and Discussion}

It was found that 1 -octyl $\beta$-D-glucoside was produced using a combination of cellulase and $\beta$ glucosidase by the one-pot synthesis of cellulose

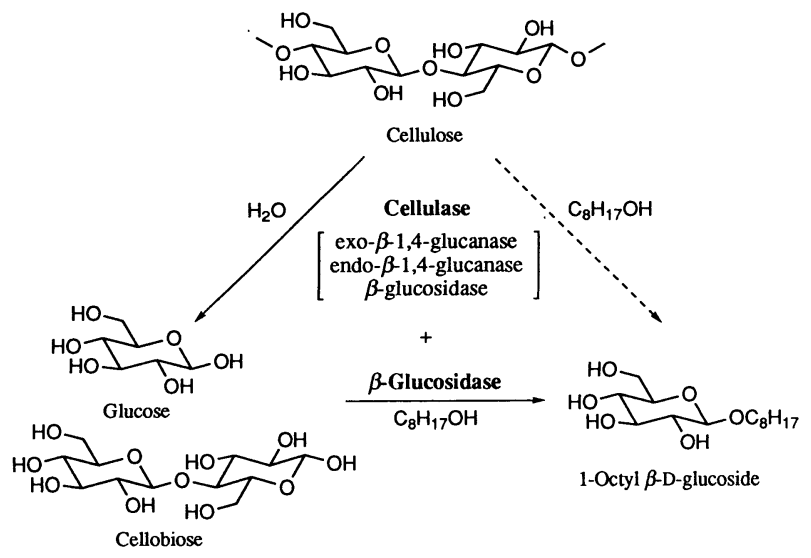

Scheme 1 
Table 1 Enzymatic Synthesis of 1-Octyl $\beta$-D-glucoside.

\begin{tabular}{|c|c|c|c|c|}
\hline Substrate & Enzyme & $\begin{array}{c}\text { Enzyme conc. } \\
(\%)\end{array}$ & Time(h) & $\begin{array}{c}\text { Yield } \\
\text { (mg/g substrate) }\end{array}$ \\
\hline $\begin{array}{l}\mathrm{D} \text {-glucose } \\
\text { cellobiose } \\
\text { cellobiose } \\
\alpha \text {-cellulose } \\
\alpha \text {-cellulose }\end{array}$ & $\begin{array}{l}\beta \text {-glucosidase } \\
\text { cellulase } \\
\beta \text {-glucosidase } \\
\text { cellulase } \\
\left\{\begin{array}{l}\text { cellulase } \\
\beta \text {-glucosidase }\end{array}\right.\end{array}$ & $\begin{array}{l}0.05 \\
0.5 \\
0.05 \\
0.5 \\
0.5 \\
0.1\end{array}$ & $\begin{array}{l}16 \\
16 \\
16 \\
16 \\
16\end{array}$ & $\begin{array}{r}120 \\
18 \\
114 \\
1 \\
125\end{array}$ \\
\hline
\end{tabular}

$0.33 \%$ D-Glucose, $0.33 \%$ cellobiose or $0.33 \%$ cellulose was reacted with 1-octanol saturated with $100 \mathrm{mM}$ acetate buffer (pH 5.0,15 mL) using cellulase, $\beta$-glucosidase or a combination of cellulase and $\beta$-glucosidase at $37^{\circ} \mathrm{C}$ for $16 \mathrm{~h}$ with stirring.

and 1-octanol in a maximum yield of $245 \mathrm{mg} / \mathrm{g}$ cellulose. Table 1 shows some yields of the 1-octyl glucoside obtained by the reaction of $\alpha$-cellulose, cellobiose or D-glucose with cellulase, $\beta$-glucosidase or a combination of cellulase and $\beta$-glucosidase. It was confirmed that octyl glucoside was produced by the reaction of D-glucose or cellobiose with $\beta$-glucosidase, or $\alpha$-cellulose with a combination of cellulase and $\beta$-glucosidase. Though a small amount of 1-octyl $\beta$-D-glucoside was produced by cellulase without $\beta$-glucosidase, this may be ascribed to the contaminated $\beta$ glucosidase in the cellulase. As measured using pnitrophenyl $\beta$-D-glucoside, the $\beta$-glucosidase activity of the cellulase was $0.57 \mathrm{unit} / \mathrm{mg}$ solid.

Fig. 1 shows the time course of the yield of 1octyl $\beta$-D-glucoside from the reaction of $0.33 \% \alpha$ cellulose and 1-octanol saturated with $100 \mathrm{mM}$ acetate buffer (pH 5, $15 \mathrm{~mL}$ ) using a combination

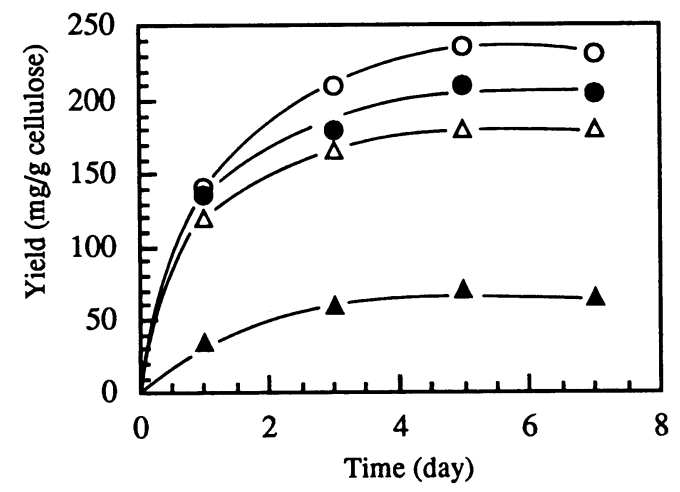

Fig.1 Time Course of 1-Octyl $\beta$-D-glucoside by the Reaction of $0.33 \%$ Cellulose and 1-Octanol Saturated with $100 \mathrm{mM}$ Acetate Buffer (pH 5.0, $15 \mathrm{~mL}$ ) Using $0.1-0.5 \%$ Cellulase and $0.1 \% \beta$-Glucosidase at $37^{\circ} \mathrm{C}$.

Cellulase : $\bigcirc: 0.5 \%, \bigcirc: 0.4 \%, \Delta: 0.3 \%, \Delta: 0.1$ $\%$ of $0.1-0.5 \%$ cellulase and $0.1 \% \beta$-glucosidase. The yield of octyl glucoside gradually increased and reached a maximum value after $5 \mathrm{~d}$ depending on the concentration of the cellulase. The yield of the octyl glucoside remained almost constant after this 5-d incubation.

Fig. 2 shows the effects of cellulase concentration on the yield of 1-octyl glucoside. It was found that the maximum yield was obtained when $0.5 \%$ cellulase and $0.1 \% \beta$-glucosidase (weight ratio of cellulase and $\beta$-glucosidase being $5 / 1$ ) was used. Both the higher and lower concentrations of cellulase decreased the yield of octyl glucoside when the concentration of $\beta$-glucosidase remained constant at $0.1 \%$.

Fig. 3 shows the effects of enzyme concentration on the yield of the octyl glucoside. It was observed that the octyl glucoside yield was slightly increased with increasing enzyme concentration up to about $0.6 \%$ when the weight ratio of cellulase and $\beta$-glucosidase was $5 / 1$. However, the differ-

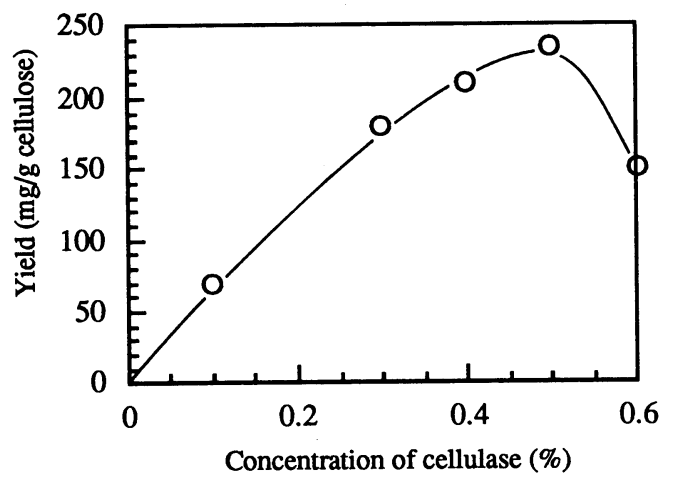

Fig.2 Effects of Cellulase Concentration on the Yield of 1-Octyl $\beta$-D-Glucoside by the Reaction of $0.33 \%$ Cellulose and 1-Octanol Saturated with 100 $\mathrm{mM}$ Acetate Buffer (pH 5.0, $15 \mathrm{~mL}$ ) Using 0.1-0.6\% Cellulase and $0.1 \% \beta$-Glucosidase at $37^{\circ} \mathrm{C}$ for $5 \mathrm{~d}$. 


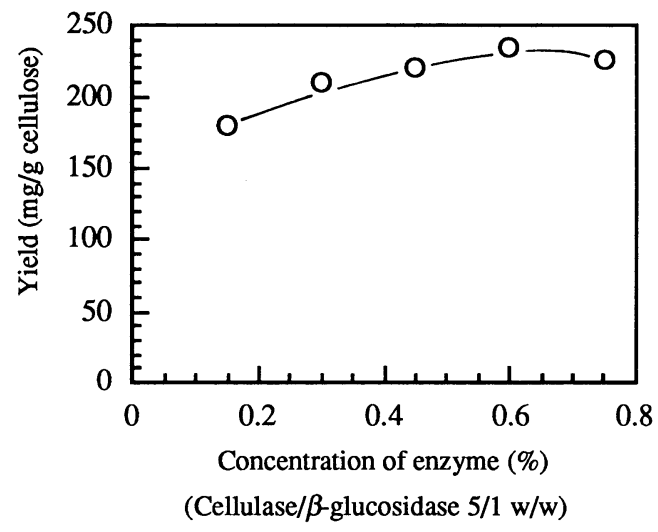

Fig.3 Effects of Enzyme Concentration on the Yield of 1-Octyl $\beta$-D-Glucoside by the Reaction of $0.33 \%$ Cellulose and 1-Octanol Saturated with $100 \mathrm{mM}$ Acetate Buffer ( $\mathrm{pH} 5.0,15 \mathrm{~mL})$ Using a Mixed Enzyme of Cellulase/ $\beta$-glucosidase Having a Weight Ratio of $5 / 1$ at $37^{\circ} \mathrm{C}$ for $5 \mathrm{~d}$.

ence in the enzyme concentration between 0.1 and $0.75 \%$ did not significantly affect the glucoside yield.

The concentration of cellulose was the decisive factor governing the octyl glucoside yield. Fig. 4 shows the effects of cellulose concentration on the octyl glucoside yield. The octyl glucoside yield quickly decreased when the cellulose concentration was higher than about $0.3 \%$ for the reaction of cellulose and 1-octanol saturated with $100 \mathrm{mM}$ acetate buffer ( $\mathrm{pH} 5.0,15 \mathrm{~mL})$ using $0.5 \%$ cellulase and $0.1 \% \beta$-glucosidase at $37{ }^{\circ} \mathrm{C}$ for $5 \mathrm{~d}$. The decrease in the octyl glucoside yield was

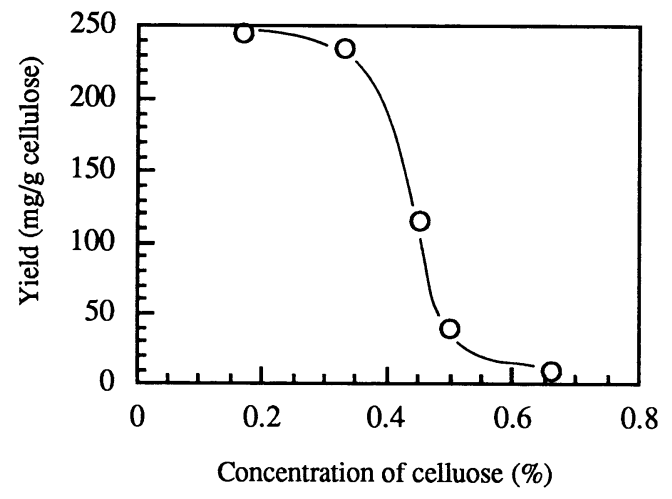

Fig.4 Effects of Cellulose Concentration on the Yield of 1-Octyl $\beta$-D-Glucoside by the Reaction of Cellulose and 1-Octanol Saturated with $100 \mathrm{mM}$ Acetate Buffer (pH 5.0, $15 \mathrm{~mL}$ ) Using 0.5\% Cellulase and $0.1 \% \beta$-Glucosidase at $37^{\circ} \mathrm{C}$ for $5 \mathrm{~d}$. ascribed to the depletion of water for effective hydrolysis of the cellulose by cellulase when an excess amount of cellulose was used.

\section{Conclusions}

It was found that 1 -octyl $\beta$-D-glucoside was produced from cellulose and 1-octanol by the action of the combined enzyme system of cellulase and $\beta$-glucosidase during a one-pot synthesis. In combination with $0.1 \%$ cellulase from Aspergillus niger and $0.5 \% \quad \beta$-glucosidase from Almonds, 1octyl $\beta$-D-glucoside was produced by as much as $245 \mathrm{mg} / \mathrm{g}$ cellulose during the incubation of $\alpha$ cellulose and 1-octanol saturated with acetate buffer $\left(\mathrm{pH} \mathrm{5.0)}\right.$ at $37{ }^{\circ} \mathrm{C}$ for $5 \mathrm{~d}$.

\section{Acknowledgment}

This work was supported by a research grant of Keio University Special Grant-in-Aid for Innovative Collaborative Research Projects.

(Received Aug. 24, 1998 ; Accepted Oct. 20, 1998)

\section{References}

1) T. Sakakibara, J. Jpn. Oil Chem. Soc., 39, 451 (1990).

2) S. Matsumura, Hyomen , 30, 991 (1992).

3) G.M. Brown, P. Dubreuil, F.M. Ichlaporia, J.E. Desnoyers, Can. J. Chem., 48, 2525 (1970).

4) K. Shinoda, T. Yamaguchi, R. Hori, Bull. Chem. Soc. Jpn., 34, 237 (1961).

5) F.A. Hughes, B.W. Lew, J. Am. Oil Chem. Soc., 47, 162 (1970).

6) D.E. Koeltzow, A.D. Urfer, J. Am. Oil Chem. Soc., 61, 1651 (1984).

7) T. Tsuchiya, S. Saito, J. Biochem., 96, 1593 (1984).

8) S. Matsumura, K. Imai, S. Yoshikawa, K. Kawada, T. Uchibori, J. Am. Oil Chem. Soc., 67, 996 (1990).

9) S. Matsumura, Y. Kawamura, S. Yoshikawa, K. Kawada, T. Uchibori, J. Am. Oil Chem. Soc., 70, 17 (1993).

10) S. Matsumura, K. Imai, S. Yoshikawa, K. Kawada, T. Uchibori, J. Jpn. Oil Chem. Soc., 40, 709 (1991).

11) K. Kawada, K. Yago, S. Zen, T. Uchibori, S. Matsumura, J. Antibact. Antifung. Agents, 22, 69 (1994).

12) H. Shinoyama, Y. Gama, H. Nakahara, Y. Ishigami, T. Yasui, Bull. Chem. Soc. Jpn., 64, 291 (1991). 
13) N. Mitsuo, H. Takeichi, T. Satoh, Chem. Pharm. Bull., 32, 1183 (1984).

14) C. Panintrarux, S. Adachi, R. Matsuno, Biotechnol. Lett., 19, 899 (1997).

15) E.M. Vulfson, R. Patel, B.A. Law, Biotechnol. Lett., 12, 397 (1990).

16) E.M. Vulfson, R. Patel, J.E. Beecher, A.T. Andrews, B.A. Law, Enzyme, Microb. Technol., 12, 950 (1990).

17) V. Laroute, R.M. Willemot, Biotechnol. Lett., 14, 169 (1992).

18) C. Panintrarux, S. Adachi, R. Matsuno, J. Mol. Cat. B: Enzymatic, 1, 165 (1996).

19) Y. Ooi, T. Hashimoto, N. Mitsuo, T. Satoh, Chem.
Pharm. Bull., 33, 1808 (1985).

20) S. Matsumura, H. Kubokawa, S. Yoshikawa, Chem. Lett., 1991, 945.

21) S. Matsumura, H. Yamazaki, K. Toshima, Biotechnol. Lett., 19, 583 (1997).

22) H. Shinoyama, Y. Kamiyama, T. Yasui, Agric. Bio. Chem., 52, 2197 (1988).

23) S. Matsumura, Y. Kinta, K. Sakiyama, K. Toshima, Biotechnol. Lett., 18, 1335 (1996).

24) S. Matsumura, K. Sakiyama, K. Toshima, Biotechnol. Lett., 19, 1249 (1997).

25) H. Shinoyama, Y. Kadoya, K. Takagi, T. Fujii, $J$. Jpn. Oil Chem. Soc., 45, 781 (1996). 


\title{
日本油化学会誌本号掲載 論文要旨
}

\section{[総説］コレステロールオキシダーゼの特性とその応用}

\author{
北本大 \\ 通産省工業技術院 物質工学工業技術研究所（开305-8565つくば市東 1-1)
}

コレステロールオキシダーゼ $(\mathrm{CO})$ は, コレステロール代謝の鍵酵素であり，ステロイドの 3 位 $\beta$ 水酸基の酸 化, 5 位二重結合の 4 位への異性化を同時に行う 2 機能性酵素である。CO は Brebivacterium, Nocardia， Psuedomonas, Rhodococcus やStreptomyces 属等の多くの土壌微生物によって生産され, 種々の分野で利用 されている産業用酵素である。今日では，血清中のコレステロールの定量試薬として臨床検査キットなどに広く使 われている。

$\mathrm{CO}$ は広い基質特異性を有しており，コレステロール以外の多種のステロイド 3 位 $\beta$ 水酸基に作用する。 $\mathrm{CO}$ は 有機溶媒中でも安定であり，また最近ステロイド系以外の化合物の位置選択的，立体選択的酸化にも利用され，リ パーゼのような日常的な有機合成試薬としての利用が期待されている。Brebivacterium 属由来の CO 3 次元構 造は既に明らかになっているが、その詳細な反応機構に関しては未だ充分な情報は得られていない。

$\mathrm{CO}$ はワタノハナゾウムシなどの害虫に対し強い殺虫活性を持つことが最近明らかになり, 害虫抵抗性作物の育 種のため CO 遺伝子の植物細胞での発現が検討されている。また，チーズやヨーグルトなどの発酵食品中のコレス テロール含量を低減させる目的で, CO 遺伝子の乳酸菌での発現も研究されている。

（連絡者：北本 大） Vol. 48, No. 1, 3 (1999)

\section{[報文 $]$ セルラーゼと $\beta$-グルコシダーゼの組み合わせによる

$$
\begin{aligned}
& \text { セルロースと1-オクタノールからの1-オクチル } \\
& \beta \text {-D-グルコシドのワンポット合成 }
\end{aligned}
$$

松村 秀一・鶴田 浩史・戸嶋 一敦

慶應義塾大学理工学部（干223-8522 横浜市港北区日吉 3-14-1）

セルラーゼとß-グルコシダーゼを組み合わせたワンポット合成によって，セルロースとオクタノールからオク

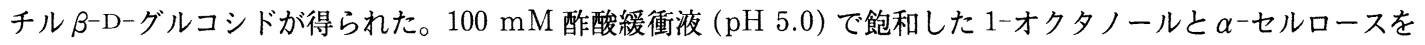

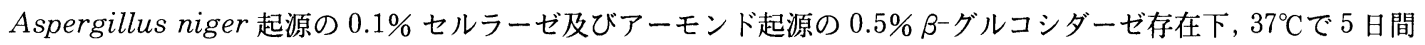

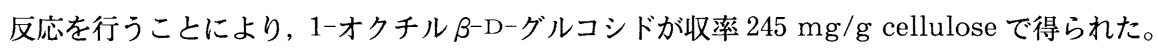

(連絡者: 松村秀一) Vol. 48, No. 1, 15 (1999) 